$4-1-2012$

\title{
The Indigenous Legal Tradition as Foundational Law
}

Christine Zuni Cruz

University of New Mexico - School of Law

Follow this and additional works at: https://digitalrepository.unm.edu/law_facultyscholarship

Part of the Indian and Aboriginal Law Commons

\section{Recommended Citation}

Christine Zuni Cruz, The Indigenous Legal Tradition as Foundational Law, Pueblo Convocation (2012).

Available at: https://digitalrepository.unm.edu/law_facultyscholarship/185

This Presentation is brought to you for free and open access by the UNM School of Law at UNM Digital Repository. It has been accepted for inclusion in Faculty Scholarship by an authorized administrator of UNM Digital Repository. For more information, please contact amywinter@unm.edu, Isloane@salud.unm.edu, sarahrk@unm.edu.

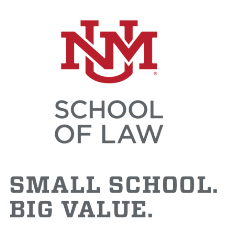

BIG VALUE. 


\title{
The Indigenous Legal Tradition As Foundational Law \\ Christine Zuni Cruz \\ University of New Mexico
}

\begin{abstract}
Author Note
Christine Zuni Cruz, School of Law, University of New Mexico

This chapter is drawn from a transcribed joint presentation made by Christine Zuni Cruz (Isleta/Ohkay Owingeh) and Casey Douma (Laguna/Hopi-Tewa) at the Pueblo Convocation in April 2012 at Tamaya. Sections I, II and V are based on the presentation made by Christine Zuni Cruz; Sections III and IV summarize the presentation made by Casey Douma. Section VI combines the concluding thoughts of Zuni Cruz and Douma. Special thanks to Aaron Sims (Acoma Pueblo) for producing the computer images for Figures 1 and 4. Figures 1 and 4 are adapted illustrations created by Christine Zuni Cruz in an earlier article (Zuni Cruz 2000). The illustrations in Figures 2 and 3 were created by Casey Douma.

Christine Zuni Cruz, School of Law, University of New Mexico; Casey Douma, Pueblo of Laguna.

Correspondence concerning this article should be addressed to Christine Zuni Cruz, MSC 11 6070, 1 University of New Mexico, Albuquerque, New Mexico, 87131-0001. E-mail: zunich@law.unm.edu.
\end{abstract}




\begin{abstract}
This paper documents the presentation provided on the Indigenous legal tradition of Pueblo peoples at the Pueblo Convocation of 2012 by Christine Zuni Cruz and Casey Douma. Section II, III and V draws from the presentation made by Zuni Cruz and identifies the Indigenous legal tradition and its operation amongst Pueblo peoples. Sections III and IV summarize Casey Douma's presentation which identified the core Pueblo institutions responsible for proper social behavior, ranging from the family, to a widening circle of Pueblo authorities. It chronicles the movement from family-centered and group resolution of disputes to the reliance on the individualized approach to resolution of disputes introduced by tribal courts.
\end{abstract}




\section{The Indigenous Legal Tradition As Foundational Law}

\section{Introduction}

The Chthonic legal tradition, or the legal tradition of Indigenous Peoples, is one of seven major legal traditions that exist in the world (Glenn, 2014, p. 261). The Chthonic legal tradition is the oldest tradition of the seven (Glenn, 2014). The common law, civil law, Talmudic, Asian, Hindu and Islamic legal traditions all "emerged in contrast to" the chthonic legal tradition (Glenn, 2014, p.62). Chthonic stems from the word autochthon, meaning "any of the earliest known dwellers in a region; an original inhabitant, an aboriginal" or "a human being living in his or her place of origin" (The New Shorter Oxford English Dictionary , 1993).

"Chthonic" was used by ecologist "Edward Goldsmith in describing people who live ecological lives by being chthonic, that is, by living in or in close harmony with the earth. To describe a legal tradition as chthonic is thus to attempt to describe a tradition by criteria internal to itself, as opposed to imposed criteria. It is an attempt to see the tradition from within, in spite of all problems of language and perception." (Glenn, 2014, p. 62, fn.6).

In this chapter, Pueblo legal tradition is used to refer generally to the Indigenous or chthonic legal tradition of the Pueblo peoples. Indigenous legal tradition and chthonic legal tradition are used interchangeably to refer to the broader legal tradition of Indigenous peoples. Pueblo legal tradition lays the foundation for Pueblo order, social structure, relationships, and conflict resolution. The Pueblo legal tradition faced tension and displacement in respect to the successive dominant civil law legal traditions introduced by the Spanish and the Mexican 
governments as each laid claim to Pueblo homelands. This tension and displacement continues under the American government.

It is in understanding the Pueblo legal tradition and its tension with the civil law and common law traditions of the successive settler nation states of Spain, Mexico and the United States, that we are able to understand and appreciate the centrality of the Pueblo chthonic legal tradition to the maintenance of Pueblo core values. The Pueblo legal tradition captures the wisdom and understandings of Pueblo ancestors over generations.

This chapter begins by considering the Indigenous (Chthonic) legal tradition in a very broad frame, some of its defining characteristics, including its existence as "living law" and its relationship to language. Next, the impact of other legal traditions on the Pueblo legal tradition, including displacement, and the presence and influence of competing traditions internally is acknowledged. Finally, the authors assert that recognizing the Pueblo legal tradition continues to operate in Pueblo communities helps to understand the challenges, both external and internal, that arise in respect to the present -day approach to "law" in Pueblo country.

\section{The Indigenous (Chthonic) Legal Tradition As Original and Foundational Law: The} Larger Frame

First and of utmost importance, is understanding that the Pueblo (chthonic) legal tradition is embedded in an Indigenous knowledge frame. Indigenous knowledge itself stems from a deep understanding of a specific "ecological order" (Battiste and Henderson, 2000, 2008, p.35). This places the Pueblo legal tradition in direct relationship with the land, which 
Pueblo peoples have occupied for thousands of years. It reflects an understanding of how nature and ecology work within specific territory, and the lessons that such understandings impart to humans. Responsibilities are associated with sustaining Indigenous knowledge, including the daily practice of that knowledge (Battiste and Henderson, 2000, 2008, p.41). Indigenous knowledge is not compartmentalized into discrete fields or disciplines. Because Indigenous knowledge stems from an ecological order, Dr. Greg Cajete (as cited in Battiste and Henderson, 1986) states Indigenous peoples across the world, though incredibly diverse, have similar knowledge frames. He notes their knowledge systems are "based on observations of processes inherent in nature," which operate according to the same basic principles (Battiste and Henderson, 2000, 2008, p. 40).

The Indigenous legal tradition is one which is primarily oral. This contrasts sharply with the written texts of the other legal traditions. The Indigenous legal tradition exists within the Indigenous knowledge frame. It is diffused throughout the knowledge frame in art, symbols, narratives, relationships, land (place), language and prayer, for example. This is one reason it is often not recognized as law. Understanding the characteristics of Indigenous knowledge helps to locate the Indigenous legal tradition. The Indigenous legal tradition is living law; it is not "past tense law" for a time long gone. It is carried in those who live it. We can say that we are socialized to the law. We can also say that we perform the law or that the law is "performancebased" (Hibbetts, 1992; Henderson, 2006, Ch. 4). It is what we are taught is the right way we were originally instructed to live, to behave, to act, and to do. 
Both the oral and the visual texts of the Indigenous legal tradition require a "jurisprudential reading." Jurisprudential reading is a critical tool for working with the Indigenous legal tradition ( see, for example, Black, 2011, p. 22; Ragsdale, 1997; Allen, 1986, Pp. 222-244). Jurisprudential reading draws the Indigenous legal tradition from "texts" not normally seen as containing law, such as, symbols, art and land - the alter/native "texts" of law. Black (2011) provides a "jurisprudential reading" of Australian Aboriginal Senior Law Men narratives, as well as contemporary literature and film. Ragsdale (1997) considers ancient Anasazi jurisprudence from unwritten "texts", ranging from architecture to symbols. Allen (1986, Pp. 222-285) instructs on how perspective is critical in understanding and interpreting stories. Jurisprudential reading involves consideration of a "text" for revelation or proper understanding in the context of the society, for the jurisprudence or the law contained in the "text", and for its meaning.

Because Indigenous knowledge stems from an ecological order, Indigenous legal tradition has the unique characteristic of being tied to the place of that particular ecology, or to the land. The knowledge imparted through a particular ecology gives the people information on how to exist and live on the land and in relationship to the land, and this information in turn is embedded in how the people relate to one another, live, and exist and this in turn, gives rise to their legal tradition.

The chthonic or Indigenous legal tradition has been affected by the other dominant legal traditions of nation states that encompass Indigenous Peoples throughout the world; as a result, no pure chthonic tradition continues to exist (Glenn, 2014, p. 83). Certainly, as extensive 
aboriginal lands were diminished and economies shifted to cash, and autonomy was affected by the external forces of successive nation states, the Pueblo legal tradition was affected. Much of the Indigenous legal tradition remains crucial, however, for societies built on relationships, tied together over generations to one another, to the land, and to its ecosystem. The core values, principles, and precepts of the Indigenous legal traditions were intended to assure this.

\section{a. Living Law - A Continual Strand}

One of the challenges to understanding the present day vitality of the Indigenous Pueblo legal tradition is the use of the English terms, "tradition" and "custom" often used in reference to Pueblo legal tradition (Zuni Cruz, 2000). Both words, through their meanings, cast law as belonging to the past, repetitive, unchanging, and while these descriptors are not entirely incorrect to use in reference to Pueblo legal tradition, they can be misleading if this rich legal tradition is understood only in these terms. They can be misleading because they do not account for the fact that the Pueblo legal tradition is living. It is a legal tradition in existence now, in the present. While its roots may extend to the past, Pueblo legal tradition, like the other major traditions, exists in the present. A legal tradition that is primarily oral in nature and which exists in the present, means that it is a legal tradition that is adhered to by those living now. A living law must be practiced or demonstrated or performed. Often, many do not realize that it is the Pueblo legal tradition that has socialized them, and because it is spoken and performed, it may not be recognized as law, or as a legal tradition. A living law is law that adapts to existing conditions, thereby challenging the notion that the Pueblo legal tradition is not capable of flexibility or adaptability. Some law may fall away and some new adaptations 
may arise, like a flowing design (Figure 1). While this is true, it is also important to point out that an aspect of the law is also immutable. That is, a part of it is not given to change - the emergence or origin story and the journey narratives, for example. This immutable law connects the People to the land. While others may view it as myth, primitive understanding, or metaphor, it is at its core, legal text that connects those, it is has long been carried by, to the land.

\section{FIGURE 1. Pueblo Living Law Through Time}
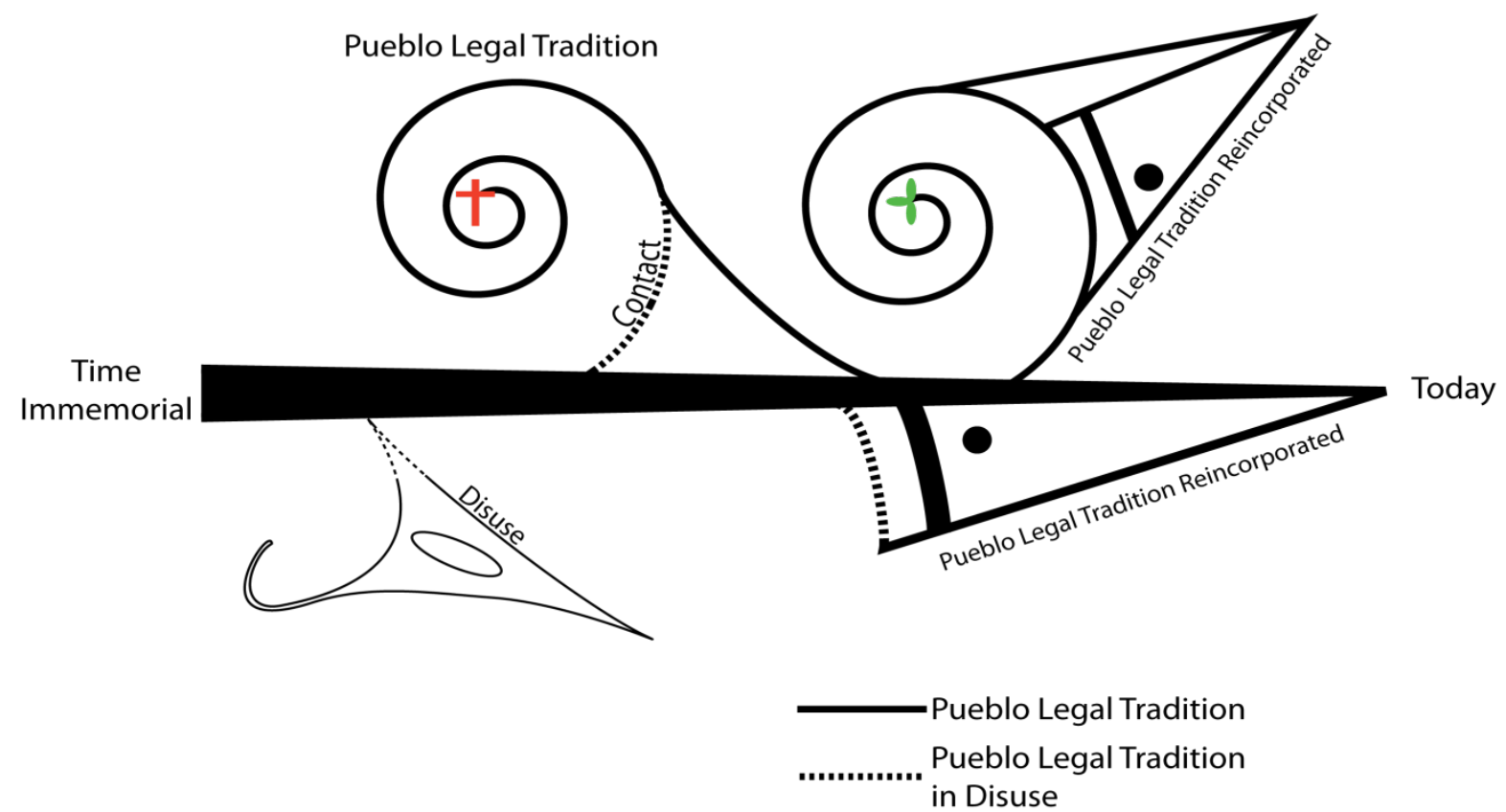

"Adapted from "Tribal Law as Indigenous Social Reality and Separate Consciousness Re\}Incorporating Customs and Traditions into Tribal Law by C.Zuni Cruz, 2000, Tribal Law Journal, Appendix A.

Knowledge of the Pueblo legal tradition internally is crucial to the preservation of core values. Acknowledgment of the Pueblo legal tradition as an existing legal tradition operating 
within Pueblo communities, both by internal and external courts, forces a dynamic interplay that is lost when only one of the legal traditions - whether it is the Pueblo legal tradition or the dominant legal tradition - is recognized as operating. The tension between the two affects both legal traditions. We engage both legal traditions and we must understand both. The American legal tradition has affected and continues to affect our lives in pervasive ways and yet our legal tradition persists. Unfortunately, the two legal traditions do not translate well across traditions, giving rise to tensions and misunderstanding when they come into contact. When one looks at the legislation and the case law affecting Indigenous Peoples, one can see the American legal tradition operates with little to no understanding of the Indigenous legal tradition. We understand this when we engage the American legal system, but we also see it within our communities where the American common law and civil legal traditions meet our Pueblo legal traditions. Some important questions we must ask include: what are the adaptations we are making in respect to law and are they complementing our Indigenous legal traditions? How are these legal adaptations we are making, whether in the written law we adopt, or the processes for settling disputes within our communities, complementing the foundational or fundamental principles of the Pueblo legal tradition? It is the challenge of creating a legal system that can meet the expectations of those who are familiar with the operation of the American common law legal tradition, while at the same time, meet the expectations of the Pueblo legal tradition, often internalized within the People themselves. It is the unresolved tensions between the two that inevitability lead to questioning from the outside and the inside.

\section{b. Language}


Indigenous language gives expression to the Indigenous knowledge frame. The concepts contained in the language give rise to an understanding that supports the underlying knowledge frame. The excavation of the Indigenous legal tradition is an endeavor that cuts across the entire Indigenous knowledge frame because Indigenous knowledge is recognized as a knowledge frame that does not "compartmentalize" knowledge into separate categories (art, law, religion, for example). Law can be found everywhere (in art and prayer, for example) and spoken word is the primary medium for conveying the law. The concepts imbedded in words and the way of thinking are essential to the legal tradition. The way of thinking imbedded in the language system supports the ideals of the Pueblo legal tradition, with both - the way of thinking, or understanding, and the ideals - intended to contribute to the sustainability of the people within the ecosystem.

\section{Impact on Pueblo Legal Tradition}

It must also be understood that the Pueblo legal tradition has been affected by the two dominant legal traditions that it has encountered, including the Spanish and Mexican civil legal tradition, and the Anglo-American legal tradition, which combines the common law and civil legal tradition. As Glenn observes, "[t]he particular genius of US law... has been its constructive combination of elements of both civil and common law" (Glenn, 2014, p. 265). When the Pueblos came within the ambit of the American legal tradition in 1848, the American treaty-making period was coming to a close and an aggressive policy period of assimilation and civilization of American Indians was underway. Shortly after New Mexico became a state in 1912, Pueblo people were recognized by the United States Supreme Court as "Indians", entitled to the same 
protections and policies of the United States government as other Indigenous Peoples in the United States. (United States v. Sandoval, 231 U.S. 28 (1913)). The federal policy at this period however was aimed at absorbing Indians within the American population. It was hostile to the recognition of a Pueblo legal tradition and the domains that support and undergird the Pueblo legal tradition, disrupting language, governance, religion, land, family structure and economics in such a manner as to transform and completely absorb Indian people into the American mainstream. The impact of this sustained policy on the Pueblo legal tradition is perhaps best understood as a continuing displacement of the Pueblo legal tradition that began under Spain and Mexico, neither of which treated the Pueblo legal tradition as on par with the civil legal tradition, barely recognizing or understanding it.

Perhaps the most obvious displacement of Pueblo legal tradition during the American period was the introduction of the Code of Federal Regulations (CFR), tribal law and order codes, American common law courts, police, judges and jails. These represent the core of the American legal tradition, including written law, the authoritative character of judges and police, the hierarchical structure of courts and the deprivation of liberty through imprisonment. "Law", authority, resolution of disputes, sanctions for wrong behavior, and process were different under the Pueblo legal tradition. While many other laws and policies impacted the Pueblos, the introduction of the American common law legal tradition within the Pueblo structure itself produced direct and on-going interaction with the Pueblo legal tradition, influencing the development of Pueblo law and legal structures.

\section{Challenges}




\section{a. Externally}

The challenges to the Pueblo legal tradition that arise externally are lack of recognition and understanding of the legal tradition. Some might say lack of recognition and understanding are the same challenges that arise internally. That may be, but once the legal tradition is recognized internally, the same barriers that arise regarding its understanding externally, do not. Our focus here, however, is on internal challenges.

\section{b. Internally}

\section{i. Imagining the Future Within}

How do we address the challenges and tensions that dominant legal traditions have created in our communities and that persist today? We can begin to imagine the future in acknowledging and strengthening the Pueblo legal tradition by creating, developing and continuing Pueblo law. There are both principles of law and lawful conduct or behavior in adherence to those principles that through their observation can restore balance to the community. As we consider law and justice, in relationship to our core values we must consider the origins and purpose of Pueblo law. When we talk about law and what it means to our people, oftentimes we think about law in the context of what is found and read in a book. As attorneys we are trained to research the law and go into the law library and look up information to find a decision that was made by a judge. But as we look into our communities and consider our rich legal tradition, we find that we are not looking into books, we are not looking into decisions made by judges, more importantly, we are looking into our core values. 
We are looking into the wisdom of elders. That is where we find our law. It is all around us and goes back to the foundation of creation.

\section{The Creator in our journey from the spiritual world to the physical world equipped us with all the tools necessary for the maintenance of balance and to maintain the spirit of harmony among our people and with all humanity.}

(Pueblo Convocation break-out sheet, 2012).

Balance is a cornerstone of Pueblo life and existence in which the commitment to attain, maintain, and reestablish balance is undertaken. For example, to love and care for one another is a method of obtaining balance in our relationship with others. Our knowledge of how we are to behave and the responsibilities we have based on our relationships to one another, assists in maintaining balance within Pueblo society. We know this, we are instructed in this, but our performance of this knowledge reaffirms that knowledge and fulfills a commitment to maintain our Pueblo legal tradition. Kinship relationships are therefore important to maintain balance within the society.

When we deviate from our knowledge of lawful behavior, we are accountable to others, including ourselves, because we recognize or others recognize, imbalance. The roles and responsibilities, which arise from our relationships to one another, play an important part in helping to identify and correct imbalance. The roles assigned to us within the family are intended to help keep others, as individuals, in balance with others. The roles and relationships we have to one another are important to maintaining family order and restoration of balance.

Within our Pueblo communities, there are various layers of accountability that we share (Figure 2). It is almost impossible to live in our communities and not know these various layers 
of accountability to one another. But within our communities, what makes our communities special, are those layers of relationships.

FIGURE 2.

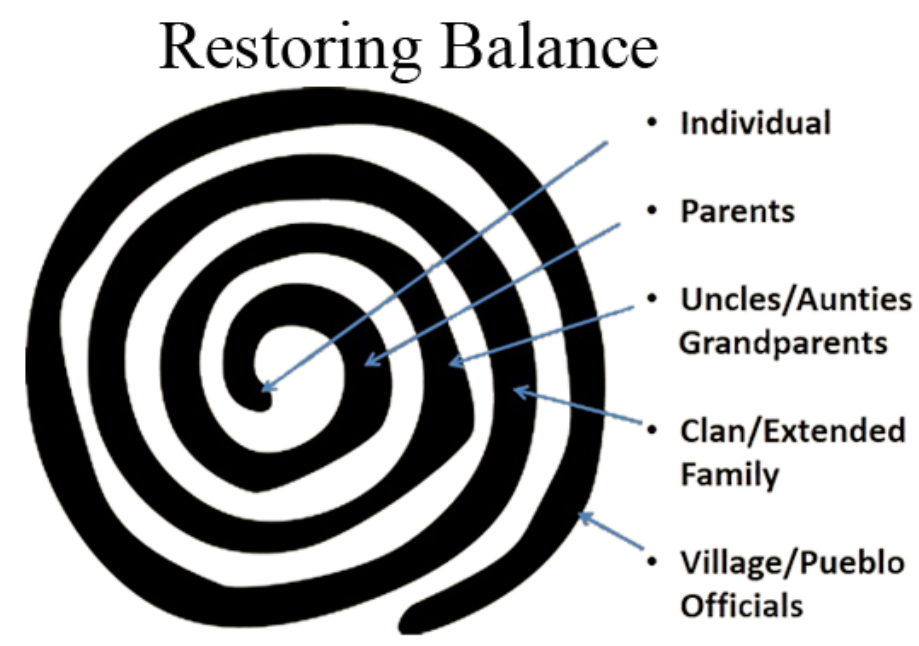

ii. Correcting Deviation and Dispute Resolution that values preservation of relationships: Communities of defined norms.

A perspective of our law is that when deviations occur we restore harmony. But we must know what harmony looks like, what love and compassion, what obedience and selfdiscipline are, because it is in knowing these that we recognize deviation. We know love, compassion, obedience, self-discipline by each one of us practicing, showing and teaching our children what they look like, what it feels like in the home. Within our villages there are people 
who do not know that they are loved, and do not know that people care for them. There are people who do not know what a healthy relationship is; these are some of the challenges we face.

Sometimes we pity others and are not firm with them, and so their deviant behavior grows. Barriers against wrong behavior weaken and lines between right and wrong fade because as a family we miss the opportunity to correct behavior. This is something that is vital to the understanding of our law - we must have the courage to talk to one another. When we do not engage as families, when we fail to be at ceremony, when we fail to be at the dance or help out during family work or village work, when we disengage ourselves it is harder to call on those individuals for help to reinforce values. It is harder to call upon one another when we do not know each other.

As communities we must strengthen our bonds with one another for the survival of our law, our way of life is dependent on our ability to maintain relationships and roles. Too often we are absent from our families, from our homes and from our communities. There is a generation of young men growing up without guidance. Will we rise to the challenge to be there for one another, to show one another we care? Words alone will not suffice. As Pueblo people we are action oriented. We live our values. Our way of life is special; it requires work, sacrifice and requires us to give of ourselves. The strength of our law depends on the strength of our families. The foundation of Pueblo law is the family. Some of the challenges that we face are related to providing the existing and coming generations with an environment where there is love and compassion in the home and with an environment where the family is always there. When we have a breakdown of our laws, our ability to address wrong behavior in our 
communities will fall on deaf ears, individuals will say, "Who gives you the right to talk to my child, who gives you the right to address their behavior?" This reinforces the importance of maintaining our relationships. We highlight this because this demonstrates our point that law is not just something found in books.

\section{Developing Sustainable Law}

\section{a. Identifying the Indigenous Legal Tradition as the Foundation: Realigning societal norms with core values.}

When we think of the future, and how to address the conditions and the things that are going on in our communities, where substance abuse, violence, and bullying can take hold of our communities, we cannot fail to understand that this environment affects our children. It is time that Pueblo people take the responsibility and re-instill the core values into our families and into our communities. We must be accountable and hold each other accountable for our actions. Our young people are depending on it.

How do we protect and provide them with an environment where there is love and compassion in the home? This is a challenge we face, but as we look at the legacy of our peoples, it reflects that since time immemorial, our legal tradition has been there with us and we have utilized it. We have honed it, generation upon generation, and we use it because it works.

There is criticism that comes from federal courts and legislators. It states, "Pueblo people, you need to change, you need to move away from your legal tradition and adopt a western 
legal system. This is the only way we will acknowledge your jurisdiction-if you have a system that looks like ours. The sooner you move away from your traditional system and the sooner you move away from a system that is reflective of your core values, the better off you will be and the sooner we will recognize your authority and ability to have jurisdiction over all people." (See, Figure 3). The Tribal Law and Order Act (25 U.S.C. § 1302 (2012)) provided that tribal

FIGURE 3.

\section{Modern Challenges}

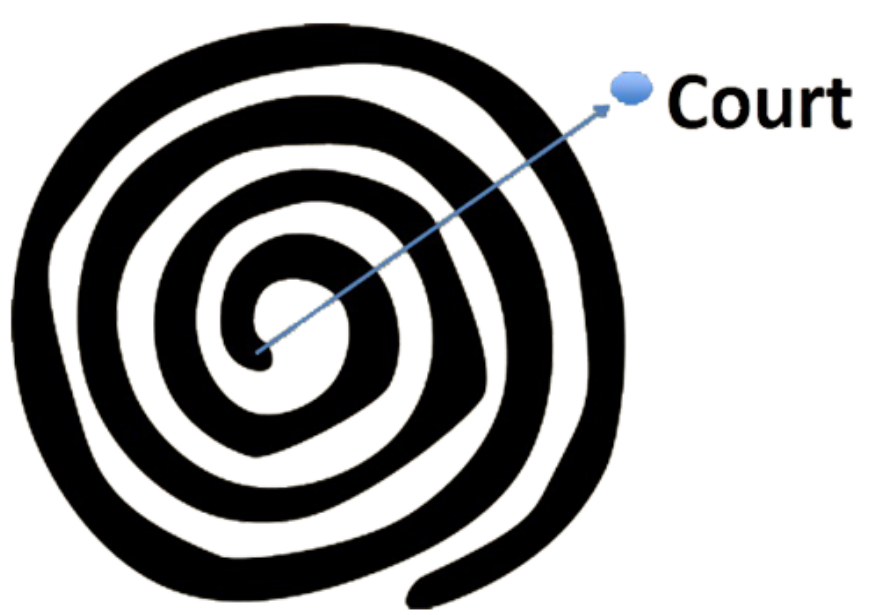

sentencing authority over Indian defendants, otherwise limited to one year incarceration and a five thousand dollar fine will expand upon a Tribal Court adhering to specific criminal procedure (25 U.S.C. § 1302 (c)). The Violence Against Women Act of 2013 (Pub.L.No. 113-4, 127 Stat 2013) provides tribal court criminal jurisdiction will be allowed over non-Indians when the Tribe adheres to specific provisions similar to the Anglo-American criminal justice system (25 U. S.C. § 1304).

We can go either way - down the path of leaving our legal traditions behind or we can say no, we have something of great benefit to our People. We have something that has sustained 
us, maintained our relationships throughout the years; something so sacred that we do not want to let go. We will be the articulators of this law and we will be articulators of this way of life and we will not adopt something that will take away from that.

\section{Pueblo Legal Tradition As Foundational}

It is important to consider how we as Pueblo people view our Pueblo legal tradition in relation to the American legal tradition already in operation in our communities to lesser or greater extents, depending on the community. As we consciously work on developing an articulation of our Pueblo legal tradition and foreground its operation within our communities, we uncover and expose it as the hidden, invisible, or unacknowledged foundation.

FIGURE 4. Pueblo Legal Tradition As Foundational Law

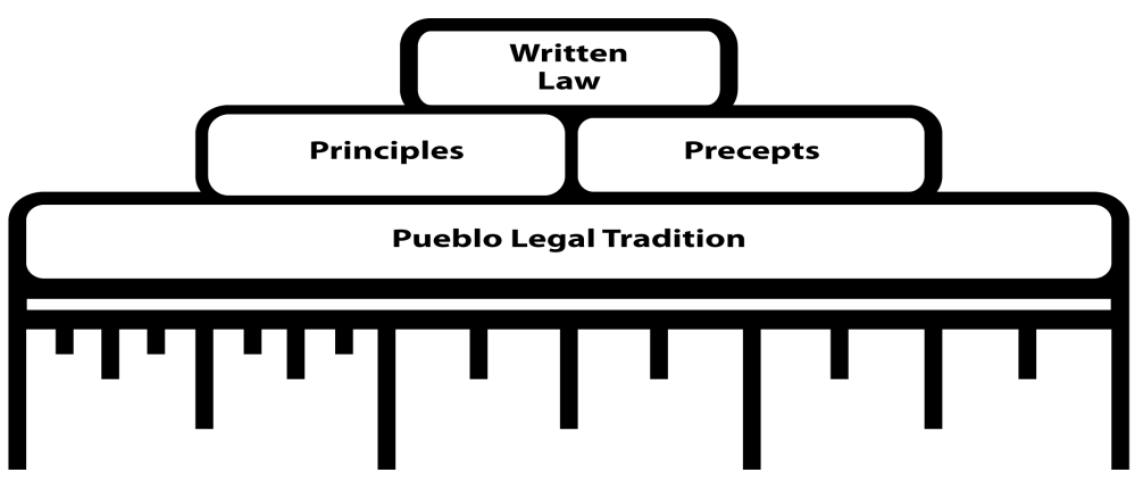

"Adapted from "Tribal Law as Indigenous Social Reality and Separate Consciousness Re\}Incorporating Customs and Traditions into Tribal Law by C.Zuni Cruz, 2000, Tribal Law Journal, Appendix B. 
Drawn from this broad foundation are the precepts and principles that we identify as emanating from our legal tradition, and which should guide the written law that we find necessary to develop and upon which that written law should be firmly set upon. Figure 4 illustrates how each successive layer is smaller, thus representing that the Pueblo legal tradition is much broader than the precepts or principles drawn from that foundation and upon which written law is based. The written law is the top layer because it represents the smallest part of a broader foundation, including underlying precepts and principles and the broader Pueblo legal tradition. The work that must be undertaken to do this is hard; it takes patience, good minds and hearts.

\section{Conclusions and Critical Questions}

First, do we have the courage to develop our law and legal systems based on the principals and precepts of our own Pueblo legal tradition? And how well equipped are we to begin the task of identifying and building on those principles, precepts or relationships to establish a system grounded on our Pueblo legal tradition?

It is the knowledge of the Pueblo legal tradition, the acknowledgment of the importance of its existence, and acting on both that will strengthen and restore the Pueblo legal tradition. As our communities work on creating and developing law within the community, it is critical to reflect on the continuation of the Pueblo legal tradition and on its value as the foundation upon which to create unique Pueblo law and process into the future. The development of the Pueblo 
legal tradition is of great importance. It is a creative force for imagining a different and unique future for law and justice within our communities.

Family is the societal and relational component of our law that is foundational. We must remind ourselves of our roles and engage those who may have been by the wayside and bring them back into the circle. Our way of life is one of acceptance. There are individuals in our communities that have strayed, that we could easily say, "forget about them, let them do their own thing." But we know that our way of life is one that is inclusive. It takes strong people to bring back into the circle those who have strayed. Our message is to encourage our fellow Pueblo people to reflect on our legal tradition. It is essential to our way of life. When there is imbalance we are to restore balance. Our children are dependent on us to provide them with this foundation, to provide them with the core values so they can carry them from this generation to the next. 


\section{REFERENCES}

Allen, P. G., (1986, 1992). The Sacred Hoop: Recovering the Feminine in American Indian Tradition. Boston, MA: Beacon Hill Press.

Battiste, M., \& Henderson, J. Y. (2000, 2008). Protecting Indigenous Knowledge and Heritage, $A$ Global Challenge ( $4^{\text {th }}$ Printing). Saskatoon, SK: Purich Publishing Ltd.

Black, C. F. (2011). The Land is the Source of the Law, A Dialogic Encounter with Indigenous Jurisprudence. Abinddon, OX: Routledge.

Brown, L. (Ed.). (1993). The New Shorter Oxford English Dictionary On Historical Principles (Vols. 1-2). New York, NY: Oxford University Press, Inc.

Glenn, H.P. (2014) Legal Traditions of the World ( $5^{\text {th }}$ ed.). New York, NY: Oxford University Press.

Henderson, J. Y. (2006). First Nations Jurisprudence and Aboriginal Rights, Defining The Just Society, Saskatoon, SK: Native Law Centre of Canada, University of SK.

Hibbitts, B.J. (1992), Coming to Our Senses: Communication and Legal Expression in Performance Cultures, Emory Law Journal, 44, Pp. 873-960.

Pueblo Convocation, To Plant, Nurture, and Harvest for our Continued Survival, Break-Out Session Sheet, April, 2012.

Ragsdale, J. W. (1997). Anasazi Jurisprudence. American Indian Law Review, 22, pp. 393444.

Zuni Cruz, C. (2000). Tribal Law as Indigenous Social Reality and Separate Consciousness [Re\}Incorporating Customs and Traditions into Tribal Law, Tribal Law Journal, 1, http://lawschool.unm.edu/tli/tribal-law-journal/articles/volume 1/zuni cruz/index.php.

\section{LEGAL REFERENCES}

Tribal Law and Order Act, 25 U.S.C. § 1302 (2012).

United States v. Sandoval, 231 U.S. 28 (1913).

Violence Against Women Reauthorization Act of 2013 (Pub. L. No. 113-4, 127 Stat 2013) (provision allowing tribal court criminal jurisdiction over non-Indians codified at 25 U.S.C.A § 1304 (West, Westlaw through P.L. 114-112 (excluding 114-92, 114-94 and 114-95)). 